\title{
Asset Bubbles, Domino Effects and 'Lifeboats': Elements of the East Asian crisis
}

Hali J. Edison, Pongsak Luangaram, and Marcus Miller

CSG R Working Paper No. 05/ 98

February 1998
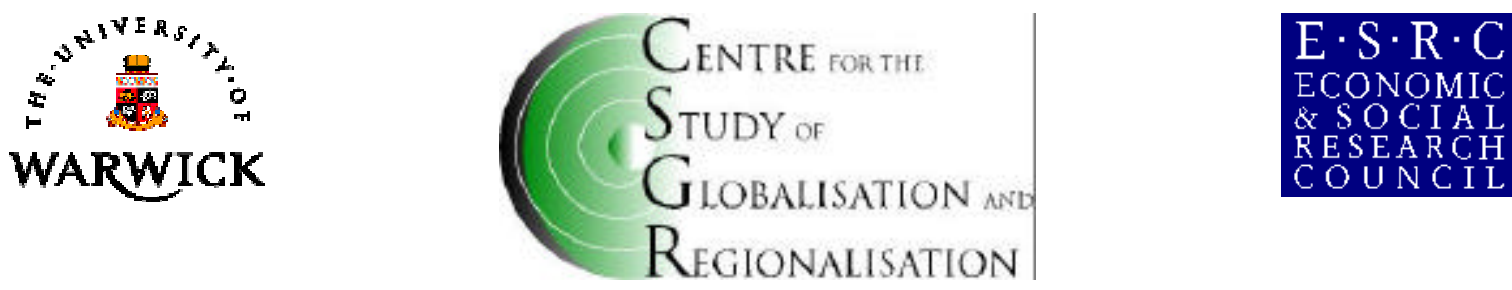

Centre for the Study of G lobalisation and Regionalisation (CSG R), University of Warwick, Coventry CV4 7AL, United-Kingdom. URL: http://www.warwick.ac.uk/fac/soc/CSGR 


\title{
Asset Bubbles, Domino Effects and 'Lifeboats': Elements of the East Asian crisis
}

\author{
Hali J. Edison, Pongsak Luangaram, and Marcus Miller
}

Board of G overnors of the Federal Reserve System ; University of Bristol ; University of Warwick and CSGR

CSG R Working Paper No. 05/ 98

February 1998

\begin{abstract}
:
Credit market imperfections have been blamed for the depth and persistence of the Great Depression in the USA. Could similar mechanisms have played a role in ending the East Asian miracle? After a brief account of the nature of the recent crises, we use a model of highly levered creditconstrained firms due to Kiyotaki and Moore (1997) to explore this question. As applied to land-holding property companies, it predicts greatly amplified responses to financial shocks - like the ending of the land price bubble or the fall of the exchange rate. The initial fall in asset values is followed by the "knockon' effects of the scramble for liquidity as companies sell land to satisfy their collateral requirements causing land prices to fall further. This could lead to financial collapse where - like falling dominoes prudent firms are brought down by imprudent firms.

Key to avoiding collapse is the nature of financial stabilisation policy; in a crisis, temporary financing can prevent illiquidity becoming insolvency and launching 'lifeboats' can do the same. But the vulnerability of financial systems like those in East Asia to short-term foreign currency exposure suggests that preventive measures are also required.
\end{abstract}

Keywords: Credit market imperfections, asset price bubbles, financial crisis, illiquidity and insolvency. JEL Classification: E32, G21, G32, G33, and O54

Address for correspondence:

Marcus Miller

Department of Economics

University of Warwick

Coventry CV4 7AL, U.K.

Tel : (44 01203) 523049

Fax : (44 01203) 523032

Email: marcus.miller@warwick.ac.uk 


\section{N ontechnical Summary:}

\section{The East Asian crisis; origin and character}

In early 1997 Korea, Indonesia, and Thailand had completed another year of rapid growth; and all three countries enjoyed a record of outstanding growth and trade performance. There were some signs of a slowdown, with large current account imbalances and stock markets past their peak, but there was no clear warning of impending financial disaster. By the end of the year all three were in the throes of severe financial crises, as reflected in the one third fall in their share prices and the collapse in the value of their currencies (by about two thirds against the dollar) despite emergency funding from the IMF.

The paper begins with brief background details on the Asian crisis, its origins and nature. While it was triggered by speculative attacks on the over-valued currencies, the crisis involved a vicious downward spiral in other financial markets. The purpose of this paper is to show how the scramble for liquidity in credit-constrained markets can rapidly turn financial boom into bust. The approach adopted here (and in earlier work on which it is based) is much the same as Krugman (1998), who observes that, to understand the crisis in Asia, one must focus on the role of financial intermediaries and the price of land and other assets.

In a globally integrated environment, with strong growth and large capital inflows (as in East Asia), credit market effects can be more pronounced than in closed economies, as capital inflows give banks and near-banks a larger supply of funds to intermediate. The lax regulation of financial institutions in East Asia meant that poor investment of borrowed funds was not uncommon, though it took different forms in different countries: in Thailand there was excessive property development, in Korea overinvestment in Chaebol, and in Indonesia, the problem of 'connected' lending.

\section{The Kiyotaki and Moore model of credit cycles}

We use the analytical framework developed by Nobuhiro Kiyotaki and John Moore (1997), hereafter KM, to show how the ending of an asset bubble and a sudden devaluation of the currency can easily lead to financial collapse.

In their basic model there are two sectors; small business which is credit constained and big business which is not. Only land can be used as collateral by low-equity, high-leverage small businesses; and their creditors (i.e., big businesses) take care never to let the amount of gross debt exceed the value of this collateral. Therefore, the rate of expansion of small businesses is determined not by their inherent value but their ability to acquire collateral.

A key feature of the basic model is that, because of credit market imperfections, a temporary shock can generate persistent fluctuations in land prices. But, in the linear quadratic formulation we specify, the equilibrium is very fragile if credit-constrained businesses finance all their land holdings by borrowing, with very little equity participation. When land prices drop unexpectedly by a small fraction, they are wiped out.

Equilibrium can be made more robust by reducing the leverage taken on by the property companies. We assume specifically that lenders impose a margin requirement $\mathrm{m}$ on borrowers (i.e., they require more equity participation and will finance only the fraction 1- $\mathrm{m}$ of land holdings).

\section{Asset bubbles}

With this framework, we examine the reaction of land allocation and land prices to two shocks which have hit East Asian economies. First, the bursting of an asset price bubble with its origins in the moral hazard problem of under-regulated financial institutions; and, second, the increase in indebtedness for firms with unhedged foreign currency liabilities due to an unanticipated devaluation.

We note specifically that in addition to paths which converge to equilibrium, there are bubble paths that diverge. Gambling financial resources on a speculative bubble is not so implausible when investors can use other people's money for the purpose. In that case, a speculative bubble may be a manifestation of moral hazard. This point has been made in the paper on "Bubbles and Crises" by Allen and Gale (1997, p.1) where they note that "historically, bubbles where asset prices quickly rise and then dramatically collapse are often followed by financial crises where default is widespread and there is negative effect on the real economy" and go on to develop "a simple theory of bubbles based on an 
agency problem... Investors use borrowed money to invest in assets. Risky assets are relatively attractive because investors can default in low payout states so their price is bid up".

What happens when an asset bubble bursts? In the absence of credit constraints, one might expect land prices to drop to equilibrium, so landholders suffer capital losses but there are no land sales. But, for highly-levered, credit-constrained firms, a fall in asset prices which reduces the value of their collateral means that loans will not be rolled over: and repayment of loans contracted when asset prices were inflated by the bubble can only be achieved by selling assets. This will cause land prices to fall further. There is a clear danger that this downward spiral in land values will reduce their net worth to zero and lead to financial collapse.

In an open economy setting, where unhedged short-term borrowing in foreign currency is a significant source of finance for land holdings, the financial sector is also vulnerable to exchange rate movements. It is not only domestic asset bubbles which can lead to the collapse of property sector: speculative attacks on currency can do so too.

By calibrating the simple linear quadratic model, we use numerical examples to see how fragile the equilibrium is. The clear message that emerges is that highly levered firms who cannot raise outside finance are very vulnerable to asset price shocks, at least when land holdings are at or close to equilibrium. This is because the initial shock is amplified by the effect of land sales by property companies whose loans have not been rolled over.

\section{Temporary financing}

One form of stabilisation is the provision of temporary finance by existing lenders (i.e., voluntary or involuntary roll-overs). So long as borrowers are still solvent after the initial shock, temporary financing can reduce (or avoid) the multiplier or 'knock-on' effects that come from the dumping of assets in a scramble for liquidity; and the emergency financing can prevent illiquidity becoming insolvency.

\section{Domino effects}

The possibility of 'domino effects' may arise where there are two types of property companies, partially levered and fully levered ('prudent' and 'imprudent'). The latter are prone to early bankruptcy which can generate significant externalities in a credit-constrained environment Prudent firms, which can survive the initial capital losses (due to bursting asset bubble, for example), may succumb when the imprudent firms are liquidated.

Domino effects may, of course, operate across sectors as well as within them, and may indeed operate across national frontiers. The failure of property companies after speculative bubble, for example, may put at risk the survival of other financial institutions such as banks and near-banks. And if other financial institutions are based in other countries, this will constitute a form of 'contagion'.

\section{Policy solutions: Handling corporate failure}

In their book on the prudential regulation, Dewatripont and Tirole (1994) list four ways for a regulatory agency to handle failure of banks. The first is liquidation, where the institution is closed and put under receivership. Second is merger where a healthy institution acquires all (or some of) failing institution's assets and liabilities. Third is the provision of loans or transfers where, for example, the supervisory agency purchases or guarantee some of the bad loans to keep the institution afloat. Fourth is nationalisation where the government take full control of the failing institutions.

\section{a) Liquidation}

In illustrating the domino effect, we had a dramatic example of the first strategy as all the imprudent companies were effectively put into receivership. It was also a warning of the risks in so doing, as the wholesale disposal of the assets of imprudent companies can put prudent companies at risk.. As the latter are essentially solvent, an obvious remedy is to provide them with temporary financing. Another is to adopt the second strategy, that of merger.

\section{b) Launching a lifeboat}

In this case, the idea is to get the prudent institutions to take over the imprudent as going concerns, which avoids wholesale liquidation and the collapse of asset prices. The Bank of England, for example, has in the past orgainised a system of lifeboats where profitable banks voluntarily take over those in trouble. As Dewatripont and Tirole pointed out the regulator may need to make cash payments or buy some of the failing institutions (bad) assets at an inflated price to facilitate the purchase. 
Alternatively, the regulator could exercise forbearance (which consists in lowering the capital adequacy requirement or not enforcing it). We argue that a combination of a lifeboat and forbearance could avert the domino effect.

c) Transfers

The third approach is the provision of loans or transfers to keep the failing institution from bankruptcy. In the context of land speculation, however, such 'transfers' could pose an enormous problem of 'moral hazard'. Far from taxing financial obligations which involve systemic risk, debt write-offs for losses incurred on unhedged borrowing act as a subsidy: and bailing out property companies from the losses they make speculating on property is a recipe for speculative frenzy and repeated calls for more forgiveness. It is presumably for this reason that the restructuring plans recommended for countries in East Asia by the international financial agencies (IMF and World Bank) eschew wholesale bailouts.

d) Nationalisation

A number of large troubled Latin-American banks were nationalised in the 1980s and in Scandinavia in the 1990s. This strategy is now being used in East Asia. In Thailand, for example, as part of the financial restructuring package recommended by the IMF, the Financial Institutions Development Fund (FIDF) is to become a major shareholder in four banks and turn them into state enterprises. e) A temporary freeze or 'circuit breaker'

Another strategy for avoiding or at least posponing the collapse of land prices has been followed in East Asia. In Thailand, for example, the operations of property companies have simply been 'frozen' since the middle of 1997. (Presumably one reason for this was the suspension and subsequent closure of 56 of the 91 finance companies who provided funds for the property companies; another is that bankruptcy law is not well-developed and the cumbersome court procedure can take up to 5 years to foreclose.)

Like the circuit breaker operated in the US stock market, this freeze may avoid panic selling: but it is unlikely to prevent a substantial mark-down in land prices when the freeze ends. (In early 1998, it was reported that the Thai Land Department was preparing to revise downward the official reference prices of land by at least 45 percent for land plots in Bangkok, its vicinity and major provinces.)

\section{Conclusion}

As applied to land-holding property companies, a model of highly-levered credit-constrained firms predicts greatly amplified responses to financial shocks - like the ending of the land price bubble or the fall of the exchange rate - which could lead to financial collapse. It illuminates role of credit market can play in financial crisis like that in East Asia. Excess credit creation can easily raise asset values above equilibrium; but when this disequilibrium is being corrected, credit constraints can set in motion a vicious downward spiral leading to complete financial collapse.

Key to avoiding collapse is the nature of financial stabilisation policy; in a crisis, temporary financing can prevent illiquidity becoming insolvency and launching 'lifeboats' can do the same. These may be effective crisis measures but the vulnerability of financial systems in East Asia to short-term foreign currency exposure suggests the need for prevention. Chile and Columbia have shown how banks can be discouraged from large-scale short-term borrowing in foreign currency: they effectively tax shortterm borrowing more than long term. The justification for such 'taxes' on capital movements is that they are designed to reduce a negative externality, namely systemic collapse. 


\title{
Asset Bubbles, Domino Effects and 'Lifeboats': Elements of the East Asian crisis
}

\author{
by \\ Hali J. Edison \\ Division of International Finance \\ Board of Governors of the Federal Reserve System \\ Washington, D.C. 20551 \\ U.S.A. \\ Pongsak Luangaram \\ Department of Economics \\ University of Bristol \\ Bristol BS8 1TN \\ U.K. \\ and \\ Marcus Miller \\ Department of Economics \\ University of Warwick \\ Coventry CV4 7AL \\ U.K \\ $\&$ \\ CEPR, London.
}

February 1998

\footnotetext{
*Acknowledgments: We would like to thank, without implicating, Timothy-James Bond and Matthew Fisher of the IMF, together with Masaki Ichikawa and Jutamas Arunanondchai for their analysis of events in East Asia, and Gabriella Chiesa, William Perraudin, Jonathan Thomas, Aubrey Wulfsohn and Lei Zhang for their comments on credit cycles. Financial support from the ESRC, under project No L120251024 "A bankruptcy code for sovereign borrowers" is gratefully acknowledged. Work on the issues treated in this paper first began when Marcus Miller was Visiting Scholar in Division of International Finance at the Federal Reserve Board and continued during a visit to the Capital Account Issues Department of the IMF: and he thanks them for their hospitality. The views expressed are solely the responsibility of the authors, however, and should not be interpreted as reflecting those of the Board of Governors of the Federal Reserve System nor of the IMF and its Executive Board.
} 


\section{Introduction}

In early 1997 Korea, Indonesia, and Thailand had completed another year of rapid growth; and all three countries enjoyed a record of outstanding growth and trade performance. There were some signs of a slowdown, with large current account imbalances and with stock markets past their peak, but there was no clear warning of impending financial disaster. By the end of the year all three countries were in the throes of severe financial crisis, as reflected in the one third fall in share prices in local currency terms and the collapse in the value of their currencies (by about a half against the dollar) despite emergency funding from the IMF.

Before the crises, their exchange rates were effectively pegged to the dollar and competitiveness was lost as the dollar strengthened. But surging capital inflows allowed an excessive credit build-up during the economic boom, financed in large part by the banks borrowing short term in foreign currency; this created overvalued assets, especially in the real estate or property sector. When the financial crisis was triggered by speculative attacks on the over-valued currencies, it rapidly led to a vicious downward spiral in other financial markets. The purpose of this paper is to show how the scramble for liquidity in credit-constrained markets can rapidly turn financial boom into bust.

There has been extensive research on the role of the banking sector in the macroeconomy and its importance in propagating business cycles; see, for example Bernanke (1983) on the Great Depression, Bernanke and Gertler (1995), King (1994), Kiyotaki and Moore (1997), and Allen and Gale (1997). These studies show how the banking sector can amplify the magnitude of the business cycle because bank credit behaves procyclically. A booming economy raises expectations about the future, increases the willingness of firms to invest and induces them to borrow more, causing an expansion in bank credit: in a downturn, loans are recalled tightening credit and exacerbating the recession. In addition, the paper by Allen and Gale emphasises the moral hazard problem that arises when investors are able to use borrowed funds so as to gain from good outcomes but avoid losses because of limited liability. 
In a globally integrated environment, with strong growth and large capital inflows (as in East Asia), these credit market effects can be more pronounced than in closed economies, as capital inflows give banks and near-banks a larger supply of funds to intermediate, allowing them to increase credit rapidly. The lax regulation of financial institutions in East Asia meant that poor investment of borrowed funds was not uncommon, though it took different forms in different countries: in Thailand there was excessive property development, in Korea overinvestment in Chaebol, and in Indonesia, the problem of 'connected' lending. For recent evidence of an association between large capital inflows, lending booms and banking/currency crises see World Bank Report (1997), Goldstein and Turner (1996), Kaminsky and Reinhart (1996) and Gavin and Hausmann (1996).

The approach taken in this paper (and in the earlier work on which it is based ${ }^{1}$ ) draws on this literature and shares the same perspective as Krugman (1998), who observes that, to understand the crisis in Asia, one must focus on the role of financial intermediaries and the price of land and other assets.

The paper is organised as follows. We begin with brief background details on the Asian crisis, its origins and nature. Section 2 outlines the analytical framework developed by Kiyotaki and Moore (1997) [henceforth KM] to show how temporary shock can generate persistent fluctuations in land prices if in the presence of credit market imperfection. In the linear quadratic formation we specify, the equilibrium is very fragile so we extend the model by introducing a margin requirement so that credit-constrained firms cannot borrow the full value of their collateral. In section 3, we examine the reaction of land allocation and land prices to two shocks which have hit East Asian economy of late. First, the bursting of an asset price bubble with its origins in the moral hazard problem of under-regulated financial institutions; and, second, the increase in indebtedness for firms with unhedged foreign currency liabilities due to an unanticipated devaluation. We use numerical examples to show that, in the absence of policy intervention, the efforts of credit-constrained firms to repay loans by selling land can easily turn illiquidity into insolvency. One form policy intervention could take is the provision of temporary finance by existing lenders (or a 'lender of last resort'): and section 4 shows how this may avert the bankruptcy of credit-constrained firms. The possibility of domino effects arises in the next section where there are two types of property companies,

\footnotetext{
${ }^{1}$ Edison and Miller (1997) and Luangaram (1997) used the similar techniques to analyse a potential collapse in the credit market after the Hong Kong handover in 1997 and the actual collapse of the Thai property market, respectively.
} 
partially levered and fully levered ('prudent' and 'imprudent'). The latter are prone to early bankruptcy which can generate significant externalities in a credit-constrained environment: prudent firms, which can survive the initial capital losses (due to bursting asset bubble, for example), may succumb when the imprudent firms are liquidated. In section 6 , four policies for handling firm failures are briefly considered in this context (namely liquidation, 'lifeboats', transfers, and nationalisation), together with a temporary freeze on land transactions. Finally, section 7 concludes.

\section{The East Asian Crisis}

\subsection{Origins}

According to Stanley Fischer, first deputy managing director of the IMF, the key domestic factors leading to the East Asian crisis were:

"first, the failure to dampen overheating pressures that had become increasingly evident in Thailand and many other countries in the region and were manifested in large external deficits and property and stock market bubbles; second, the maintenance of pegged exchange rate regimes for too long, which encouraged external borrowing and led to excessive exposure to foreign exchange risk in both the financial and corporate sectors; third, lax prudential rules and financial oversight which led to a sharp deterioration in the quality of banks' loan portfolios...

Although the problems in these countries were mostly homegrown, developments in the advanced economies and global financial markets contributed significantly to the build-up of the imbalances that eventually led to the crises. In many respects, Thailand, Indonesia, and Korea do face similar problems. They all have suffered a loss of confidence, and their currencies are deeply depreciated." Fischer (1998, p.21).

\subsection{Development in Asset prices}

Summary evidence of overall macroeconomic conditions in what we will refer to as the KIT economies is provided in Appendix 1, Tables A.1 - A.3. Here, we give a brief account of asset prices and the state of short-term indebtedness.

\section{Equity market and the value of property companies}


Though stock markets had been falling in Korea and Thailand in 1995 and 1996, there was a spectacular drop in share prices in the second half of 1997, when the stock markets in Korea and Indonesia fell by about 38 percent and in Thailand by 56 percent.

Table 1

Share prices

\begin{tabular}{llrrrrr}
\hline & & 1993 & 1994 & 1995 & 1996 & 1997 \\
\hline Korea & Overall & 866.2 & 1024.6 & 882.9 & 651.2 & 376.3 \\
& Property & 458.0 & 591.8 & 430.0 & 295.3 & 103.1 \\
Indonesia & Overall & 587.9 & 469.6 & 513.9 & 637.4 & 401.7 \\
& Property & $\mathrm{n} / \mathrm{a}$ & $\mathrm{n} / \mathrm{a}$ & 100.0 & 143.7 & 72.0 \\
\multirow{3}{*}{ Thailand } & Overall & 1682.9 & 1360.1 & 1280.8 & 831.6 & 365.8 \\
& Property & 2266.6 & 1194.7 & 951.0 & 523.5 & 95.6 \\
\hline
\end{tabular}

It is believed that a substantial part of the capital inflows were invested in real estate; and the price of land is what we highlight in the model that follows. As early as 1996 there were signs of a deteriorating real estate market; and the risk that this posed was noted in the IMF World Economic Outlook (December 1997 p.69 Box 1): “The investment in real estate was generated partly by inflation in property values associated with the overheating of the economy, while the quality of the banking system's loan portfolio became increasingly dependent on the maintenance of property prices, since real estate was the main collateral for loans to this sector."

While it is difficult to obtain data on property prices per se, we can report share prices for property companies listed on the stock exchanges. As shown in Table 1, from 1995 to 1996 the value of property companies (measured in local currency) rose by around 40 percent in Indonesia but fell about a third in Korea and a half in Thailand. In 1997, property shares in Indonesia lost half their value; and in Korea and Thailand the decline accelerated. By the end of the year ${ }^{2}$, property companies in Thailand were worth only 10 percent of their value 24 months before.

\footnotetext{
${ }^{2}$ In early 1998, it was reported that the Land Department in Thailand, having "surveyed 10 locations in Bangkok and found that land prices in some areas had plunged by more than $60 \%, \ldots$ was preparing to revise
} 


\section{Foreign exchange market and short-term currency exposure}

Until 1997, macroeconomic management in most emerging markets - including the KIT economies - involved effectively pegging the exchange rate against the US dollar (even though, as the dollar appreciated against the $\mathrm{yen}^{3}$, this led to an increasing loss of trade competitiveness and export shares). In response to capital inflows during the 1990s, central banks intervened to prevent exchange rate depreciation; and later, when capital flows reversed themselves, central banks used their foreign exchange reserves to resist downward pressure on the exchange rate - as long as reserves lasted.

Table 2 shows the stability of the exchange rates prior to 1997 and the dramatic depreciation since then, which roughly doubled the local currency cost of the dollar by the end of that year. As most of the short-term borrowing was not hedged, the 100 percent rise in the price of the dollar meant a sharp rise indebtedness, threatening many firms with insolvency.

Table 2

Movement in exchange rate (end-of-period per US\$)

\begin{tabular}{lrrrrrrrr}
\hline & 1991 & 1992 & 1993 & 1994 & 1995 & 1996 & $\begin{array}{r}1997 \\
\text { 1996-1997 } \\
\text { change }\end{array}$ \\
\hline Korea & 765.3 & 791.5 & 811.3 & 792.7 & 775.8 & 847.5 & 1695.0 & 100.0 \\
Indonesia & 2000.0 & 2070.4 & 2112.0 & 2202.6 & 2289.0 & 2361.0 & 5650.0 & 139.0 \\
Thailand & 25.3 & 25.5 & 25.6 & 25.1 & 25.2 & 25.7 & 46.8 & 82.4 \\
\hline
\end{tabular}

The overall extent of foreign currency exposure in the KIT economies is given in Appendix 1. In 1996, for example, short-term foreign currency indebtedness was about 16 percent of GDP for Korea, 13 percent of GDP for Indonesia, and 20 percent of GDP for Thailand.

\section{Kiyotaki and Moore's model of credit cycles}

In this paper, we adopt the 'credit-constrained' framework of Kiyotaki and Moore (1997), hereafter KM, to illustrate aspects of the East Asian crisis. Before using it to show how the ending of an asset bubble and a sudden devaluation of the currency can easily lead to financial 
collapse, in this section we provide a simple linear quadratic formulation of their model and extend it to include margin requirements.

\subsection{The basic KM model}

There are two sectors what we might call Big Business (which is not credit constrained) and Small Business (which is credit constrained) - which KM refer to as 'gatherers' and 'farmers' respectively. As the technology in the small business sector is idiosyncratic and involves human capital, there is a moral hazard problem - if the small firms has a lot of debt, they may find it advantageous to threaten creditors with debt repudiation.Creditors (i.e., big businesses) protect themselves from this threat of repudiation by demanding collateral in a form of land; and they take care never to let the amount of gross debt exceed the value of this collateral. Hence, the rate of expansion of these highly levered, credit-constrained small businesses is determined not by their inherent earning power but their ability to acquire collateral.

In the absence of surprises, the quantity of land held by the small business sector, denoted $\mathrm{k}_{\mathrm{t}}$, is determined as follows. We begin with the - slightly simplified - budget constraint:

$$
\mathrm{q}_{\mathrm{t}}\left(\mathrm{k}_{\mathrm{t}}-\mathrm{k}_{\mathrm{t}-1}\right)+\mathrm{Rb}_{\mathrm{t}-1}=\alpha \mathrm{k}_{\mathrm{t}-1}+\mathrm{b}_{\mathrm{t}}
$$

\section{LAND ACCUMULATION + DEBT REPAID = INCOME + BORROWING}

where $b_{t}$ is the amount of one-period borrowing, repaid as $R b_{t}$ (where $R$ is one plus one-period interest rate), $\mathrm{q}_{\mathrm{t}}$ is price of land, and $\alpha$ measures the productivity of land in small business sector

Assuming borrowing gross of interest is chosen to match the expected value of collateral implies

$$
\mathrm{b}_{\mathrm{t}}=\mathrm{q}_{\mathrm{t}+1} \mathrm{k}_{\mathrm{t}} / \mathrm{R}, \quad \mathrm{b}_{\mathrm{t}-1}=\mathrm{q}_{\mathrm{t}} \mathrm{k}_{\mathrm{t}-1} / \mathrm{R}
$$

so after substitution in (1), one obtains

$$
\left(\mathrm{q}_{\mathrm{t}}-\mathrm{q}_{\mathrm{t}+1} / \mathrm{R}\right) \mathrm{k}_{\mathrm{t}}=\alpha \mathrm{k}_{\mathrm{t}-1}
$$

where the LHS measures the net-of-borrowing costs of acquiring land $\mathrm{k}_{\mathrm{t}}$ and the RHS measures the net worth ${ }^{4}$ of the firms at beginning of the period. As KM (1997, p.220) remark, the firms use all their "net worth to finance the difference between price of land, qt and the

\footnotetext{
${ }^{3}$ From mid 1995 to end 1997, the dollar appreciated by 50 percent against the yen.

${ }^{4}$ By definition, the net worth of a small businesses at the beginning of date $t$ is the value of tradable output and land held from the previous period, net of debt repayment i.e., $\left(\alpha+q_{t}\right) k_{t-1}-R_{t-1}=\alpha k_{t-1}$.
} 
amount they can borrow against a unit of land , $\mathrm{q}_{\mathrm{t}+1} / \mathrm{R}$. This difference $\mathrm{q}_{\mathrm{t}}-\mathrm{q}_{\mathrm{t}+1} / \mathrm{R}$ can be thought of as the down payment required to purchase a unit of land".

The arbitrage condition for other users of land, who are assumed not to be credit constrained, implies

$$
\mathrm{f}\left(\mathrm{k}_{\mathrm{t}}\right)+\mathrm{q}_{\mathrm{t}+1}-\mathrm{q}_{\mathrm{t}}=(\mathrm{R}-1) \mathrm{q}_{\mathrm{t}}
$$

where $\mathrm{f}\left(\mathrm{k}_{\mathrm{t}}\right)$ is the marginal productivity of land in the unconstrained sector ${ }^{5}$; or, as KM put it,

$$
\left(\mathrm{q}_{\mathrm{t}}-\mathrm{q}_{\mathrm{t}+1} / \mathrm{R}\right)=\mathrm{f}\left(\mathrm{k}_{\mathrm{t}}\right) / \mathrm{R}=\mathrm{u}\left(\mathrm{k}_{\mathrm{t}}\right)
$$

where $\mathrm{u}\left(\mathrm{k}_{\mathrm{t}}\right)$ is the discounted marginal productivity of land in the unconstrained sector (which, because of arbitrage, we refer to as the user cost of land in what follows).

Substituting (5) into (3), i.e., equating the down payment required to purchase a unit of land to the user cost, gives

$$
\mathrm{u}\left(\mathrm{k}_{\mathrm{t}}\right) \mathrm{k}_{\mathrm{t}}=\alpha \mathrm{k}_{\mathrm{t}-1}
$$

For simplicity of exposition, we begin by assuming that the user cost is proportional to $\mathrm{k}_{\mathrm{t}}$, specifically:

$$
\mathrm{u}\left(\mathrm{k}_{\mathrm{t}}\right)=\frac{\beta}{\mathrm{R}} \mathrm{k}_{\mathrm{t}}
$$

where $\beta$ is a constant

Combining (6) and (7) yields a non-linear difference equation which can be written:

$$
\mathrm{k}_{\mathrm{t}}=\sqrt{\frac{\mathrm{R} \alpha}{\beta}} \mathrm{k}_{\mathrm{t}-1}^{1 / 2 .}
$$

and the dynamics of land accumulation in the absence of shocks is shown in Fig. 1, where the top panel plots $\mathrm{k}_{\mathrm{t}}$ as the non-linear function of $\mathrm{k}_{\mathrm{t}-1}$ given in (8) above. There are evidently two equilibria, one at zero and the other at $\mathrm{k}^{*}=\mathrm{R} \alpha / \beta$; the latter is stable while the former is not.

\footnotetext{
${ }^{5}$ Note that this can be written as an increasing function of land holdings in the constrained sector if the total of land holdings in both sectors is a constant.
} 


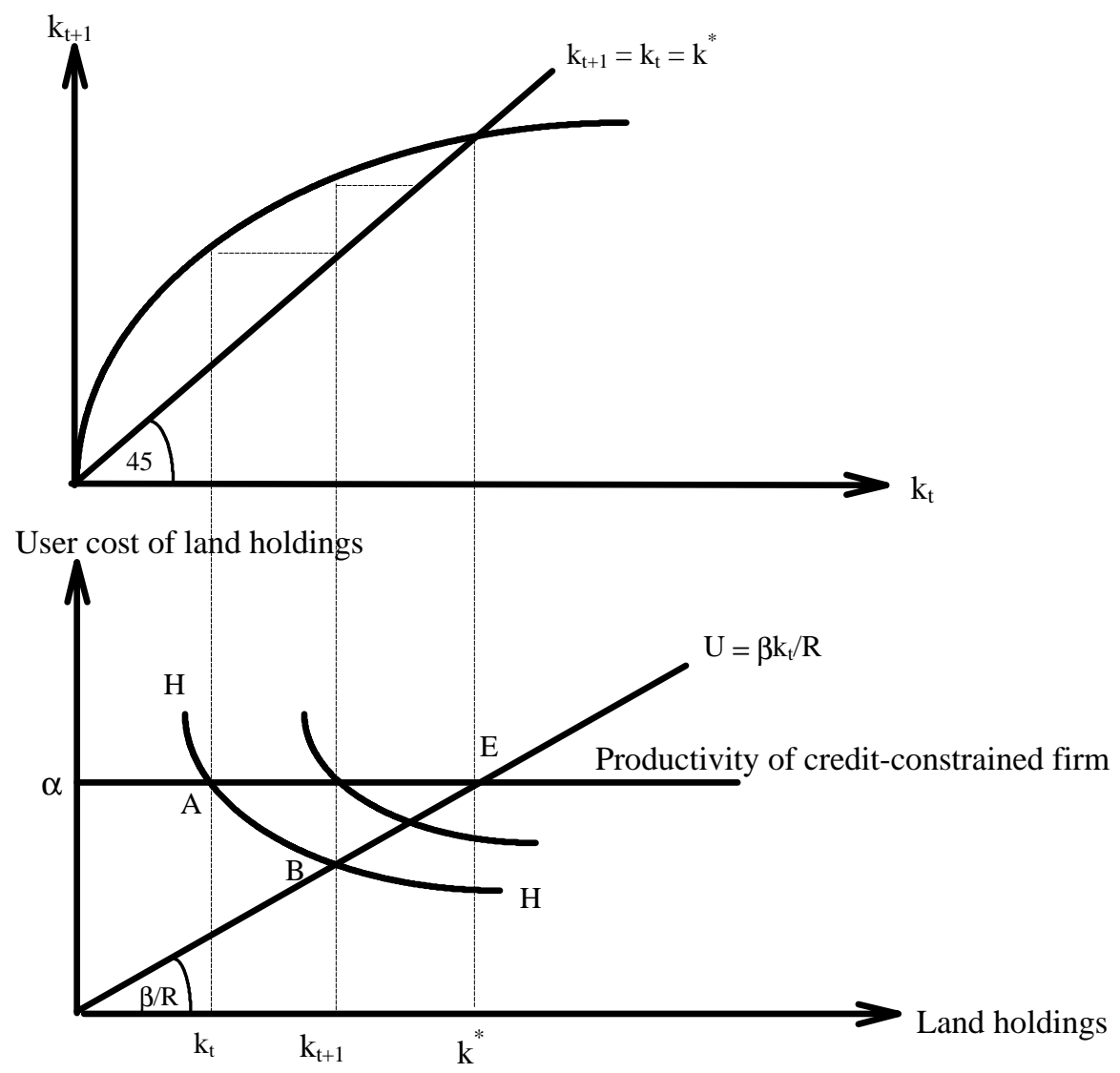

Fig.1. Dynamics of the KM model with no surprises

The path of convergence to $\mathrm{k}^{*}$ from an initial value of $\mathrm{k}_{\mathrm{t}}<\mathrm{k}^{*}$ can also be seen in the lower panel where the vertical axis measures its productivity in the small business and the user cost of land (its discounted productivity in the other sector). As (6) requires that $\alpha \mathrm{k}_{\mathrm{t}-1}$ (i.e., net worth) should be set equal to $\mathrm{u}\left(\mathrm{k}_{\mathrm{t}}\right) \mathrm{k}_{\mathrm{t}}$ (today's holdings times the user cost), this means the points labelled A and B must lie on the same rectangular hyperbola, labelled $\mathrm{HH}$ in the figure. This illustrates how to find $\mathrm{k}_{\mathrm{t}}$ given $\mathrm{k}_{\mathrm{t}-1}$. On the same principle, land holding in periods $\mathrm{t}+1$ can be found by shifting the hyperbola to the right as shown.

The value of land is given by the present discounted value of its user cost i.e.,

$$
\mathrm{q}_{\mathrm{t}}=\sum_{\mathrm{i}=\mathrm{o}}^{\infty} \frac{\mathrm{u}\left(\mathrm{k}_{\mathrm{t}+\mathrm{s}}\right)}{\mathrm{R}^{\mathrm{s}}}
$$

where the user costs are measured along the path towards equilibrium.

Before adding extra features to their model, KM use it to study the effects of a temporary productivity shock which unexpectedly raises the parameter $\alpha$ by $\Delta \alpha$ for one period only; and they show that because the small business sector is credit-constrained, this has effects on the value and allocation of land which persist beyond one period. They emphasise 
that this unexpected rise in productivity not only eases the borrowing constraint on small businesses directly by raising $\alpha$ in (6), it also helps indirectly by raising the price of their land, which (because debt is not indexed) raises their net worth.

Note that, in the face of a one-time productivity shock which occurs when the system is in equilibrium, (6) needs to be recast as:

$$
\mathrm{u}\left(\mathrm{k}_{\mathrm{t}}\right) \mathrm{k}_{\mathrm{t}}=\left(\alpha+\Delta \alpha+\mathrm{q}_{\mathrm{t}}-\mathrm{q}^{*}\right) \mathrm{k}^{*}
$$

where $\Delta \alpha$ is the 'direct' effect of the productivity gain and $\mathrm{q}_{\mathrm{t}}-\mathrm{q}^{*}$ is the 'indirect' effect due to the rise in land prices. (In the KM model, the credit-constrained land users have an incentive to get more land than in the market equilibrium as land yields them a non-marketable product $\gamma$ which makes its total productivity $\alpha+\gamma$ : but this is not relevant for our purpose which is to look at contractions.)

\subsection{The introduction of a margin requirement}

A key feature of the basic KM model is that the equilibrium at $\mathrm{E}$ is very fragile. Creditconstrained businesses have financed all their land holdings by borrowing and have very little zero net worth (actually only $\alpha \mathrm{k}^{*}$ in equilibrium, i.e., one period's flow of income). So, if land prices drop unexpectedly by a small fraction, they are wiped out.

Kiyotaki and Moore go on to introduce other mechanisms which have the effect of damping the response to exogenous shocks. In this paper, however, we stick with their simple model but reduce its fragility by reducing the leverage taken on by the property companies. We assume that lenders impose a margin requirement on borrowers: specifically they require equity participation of $\mathrm{m}$ and will lend only the fraction $1-\mathrm{m}$ of the value of land. One motivation for this is suggested by KM (1997, p.221), namely the cost of liquidation. If legal and other costs were expected to be the fraction $\mathrm{m}$ of land values, then bankers looking for complete collateralisation would need to constrain their lending appropriately.

While this does probably account for some fraction of observed margin requirements, there are two additional reasons that seem much more relevant here. The first is that, given the fragility of equilibrium, they are necessary for 'prudential reasons' i.e., to prevent borrowers going bankrupt too often. (The simulations reported below make this point very forcefully.) The other reason is to combat a form of moral hazard not included in the $\mathrm{KM}$ model ${ }^{6}$, namely

\footnotetext{
${ }^{6}$ As mentioned above, Kiyotaki and Moore do consider the moral hazard arising from the idiosyncratic technology of credit-constrained borrowers (for which the solution is collateralised debt).
} 
the incentive that low capitalisation gives to owners of property companies to invest in highvariance projects ${ }^{7}$ - the well-known incentive to 'gamble for resurrection'. Before the crisis, we can report that major banks in Thailand, for example, limited lending to about 70-80 percent of value of collateral. After the crisis, however, the requirement for equity participation has increased sharply, with lending now limited to between 50-60 percent of the value of collateral, i.e., $\mathrm{m}$ has been increased from 0.2/0.3 to 0.4/0.5, (Business Day, financial section, 20/2/98). In the light of these figures, we set $\mathrm{m}$ equal to 0.3 in simulations below.

The detailed implications of introducing a margin requirement are spelt out in Luangaram (1997) and the relevant formulae are reproduced in the Appendix 2. Here, we simply indicate how it slows the adjustment of land holdings (and increases the long run equilibrium).

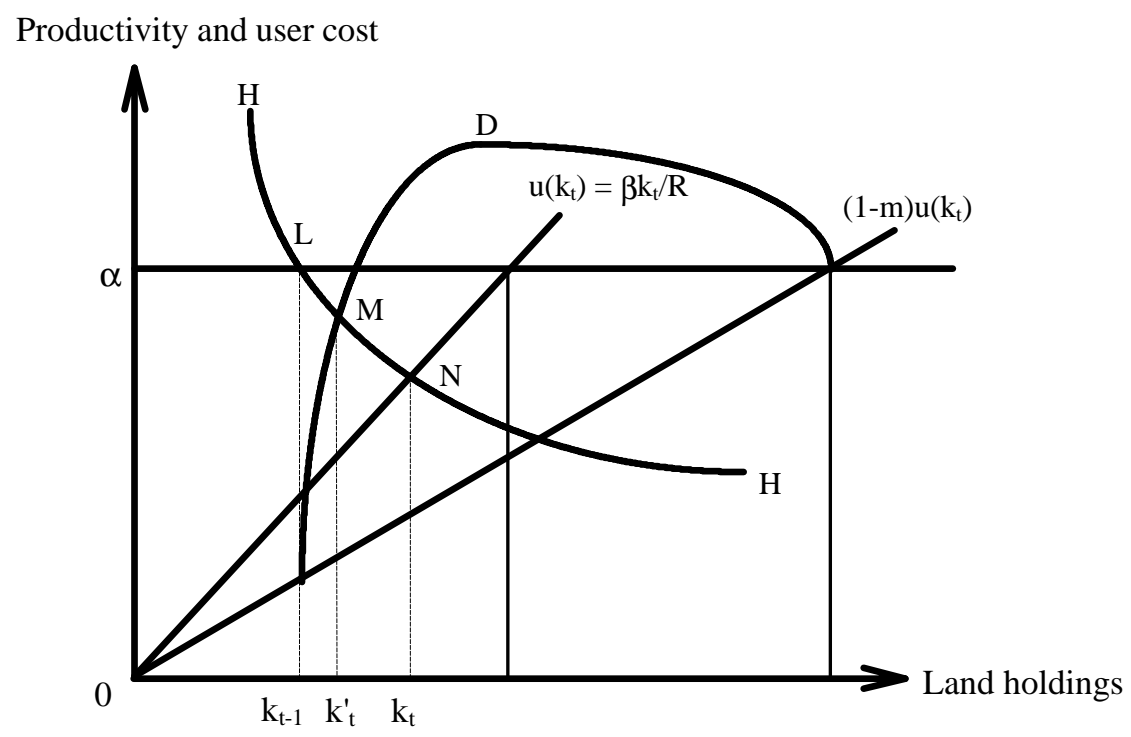

Fig. 2. Dynamic adjustment where $m>0$

As can be seen from (A.3) in Appendix 2, a margin requirement implies that the 'down payment' must exceed the user cost of land. How this affects the adjustment can be seen in Fig.2, constructed along the same line as Fig.1. Starting at point $\mathrm{L}$, where $\mathrm{k}=\mathrm{k}_{\mathrm{t}-1}$. With no margin requirement and starting at point $\mathrm{L}$, where $\mathrm{k}=\mathrm{k}_{\mathrm{t}-1}$, land purchases would take land holdings to $\mathrm{k}_{\mathrm{t}}$ where the net worth, shown as $\mathrm{HH}$, matches the user cost schedule, $\mathrm{u}\left(\mathrm{k}_{\mathrm{t}}\right)$, at

\footnotetext{
${ }^{7}$ See, for example, Dewatripont and Tirole, 1994, chapter 8 for a demonstation that "shareholders'bias toward risk is stronger, the lower the bank's solvency"
} 
point $\mathrm{N}$. With a margin requirement of 50 percent, the down payment is shown by the curve $\mathrm{D}$, equal to half of the linear function $\mathrm{u}\left(\mathrm{k}_{\mathrm{t}}\right)$ plus half $\mathrm{q}_{\mathrm{t}}\left(\mathrm{k}_{\mathrm{t}}-\mathrm{k}_{\mathrm{t}-1}\right)$, the money needed for new land holdings (an approximately quadratic function of $\mathrm{k}_{\mathrm{t}}$ ). As is evident from the figure, the requirement to find half of the money for new land purchases out of current profit slows the expansion, to $\mathrm{k}_{\mathrm{t}}$ less than $\mathrm{k}_{\mathrm{t}}$. It is also clear that equilibrium level of land holdings doubles: as firms with only half of leverage are effectively making greater use of equity finance. (In the KM model, this means that in long-run equilibrium the higher margin requirement raises the consumption of non-traded goods. The reason why firms would not voluntarily choose to increase their margin requirement is presumably that consumption would have to fall substantially for long period to bring down debt holdings.)

\section{Bursting bubbles and escalating debts}

As shown earlier, the value of property companies in the stock markets of the KIT economies dropped between a third and a half from 1995 to 1996; and in 1997, the dollar values of their currencies fell by about a half. How do the credit constraints operate if there is an asset bubble which bursts? This is analysed in the first part of this section, using the KM model where we interpret the credit-constrained firms as property companies and include, in the other (unconstrained) sector, the banks and finance houses which lend to them. In the second part, we discuss the effects of a sudden increase in indebtedness of credit-constrained firms with substantial unhedged foreign currency borrowing, due to an unexpected devaluation.

\subsection{Asset bubbles}

Kiyotaki and Moore focus on solution paths which converge to equilibrium. As this is a saddlepoint equilibrium, however, there are also paths that diverge, as shown in Fig. 3. In the absence of future changes, these paths are essentially asset bubbles. Gambling financial resources on a speculative bubble is not so implausible when investors can use other people's money for the purpose. In that case, a speculative bubble may be another manifestation of moral hazard. This point has been made in the paper on "Bubble and Crises" by Allen and Gale (1997, p.1) where they note that "historically, bubbles where asset prices quickly rise and then dramatically collapse are often followed by financial crises where default is widespread and there is negative effect on the real economy" and go on to develop "a simple theory of bubbles based on an agency problem... Investors use borrowed money to invest in assets. Risky assets are relatively attractive because investors can default in low payout states so their price is bid 
up". (Krugman (1998) also stresses the role of moral hazard in his description of the bubble economies in Asia.)

In the context of the KM model we are using, the credit constraints applied to the property companies were themselves due to a moral hazard problem, the risk that the firms would not repay debts over and above the value of collateral. It is worth stressing that the problem being discussed here is in the unconstrained sector: it is the 'finance houses' in that sector who have access to plentiful funds in domestic and international markets which they can advance to property companies. Two additional facts are relevant here, first is the weak regulation of the finance companies and near-bank intermediaries which characterised East Asian economies. Second, we note that 56 of the 91 finance companies have in fact been closed down in Thailand, in large part because of property lending that went bad. So, the tale we tell with the aid of the KM model is one of credit constraint in small business and unregulated moral hazard in big business ${ }^{8}$. It pertains more clearly to Thailand than the other two KIT economies; but doubtless appropriate variants can be constructed for Korea and Indonesia (cf. Bond and Miller (1998), for example).

Consider a bubble on the unstable path leading directly upwards from equilibrium at $\mathrm{E}$ in Fig. 3 and assume that lenders effectively ignore the probability of the bubble bursting ${ }^{9}$. On such a dynamic path, as can be seen from (5) and (7) and setting $\mathrm{k}_{\mathrm{t}}=\mathrm{k}^{*}$, asset prices which begin above equilibrium will keep growing at a speed given by $\mathrm{q}_{\mathrm{t}+1}=\mathrm{Rq}_{\mathrm{t}}-\beta \mathrm{k}^{*}$ where the autoregressive coefficient, $\mathrm{R}$, is clearly larger than unity $(\mathrm{R}$ is one plus short-term rate of interest).

Let the bubble burst when land values reach the level labelled $\mathrm{q}^{\mathrm{b}}$ in the top panel of Fig. 3. In the absence of credit constraints, one might expect a return to equilibrium at $\mathrm{E}$ as asset prices drop to $\mathrm{q}^{*}$. Landholders would suffer capital losses but there are no land sales. For highly-levered, credit-constrained firms, however, a fall in asset values which reduces the value of collateral means that loans will not be rolled over. Repayment of borrowing made when asset prices were inflated by the bubble can only be achieved by selling assets. This will cause land values to fall further.

\footnotetext{
${ }^{8}$ Note that, as discussed earlier, another form of moral hazard (not included in the KM model) may arise in highly-levered credit-constrained businesses which have an incentive to 'gamble for resurrection'.

${ }^{9}$ One could perhaps model the moral hazard problem in the lending companies and on the assumtion that it is a 'rational bubble', with a known bursting probability of $\mathrm{p}$ and a faster rate of expansion, as discussed in Blanchard and Fischer (1989, p.222).
} 


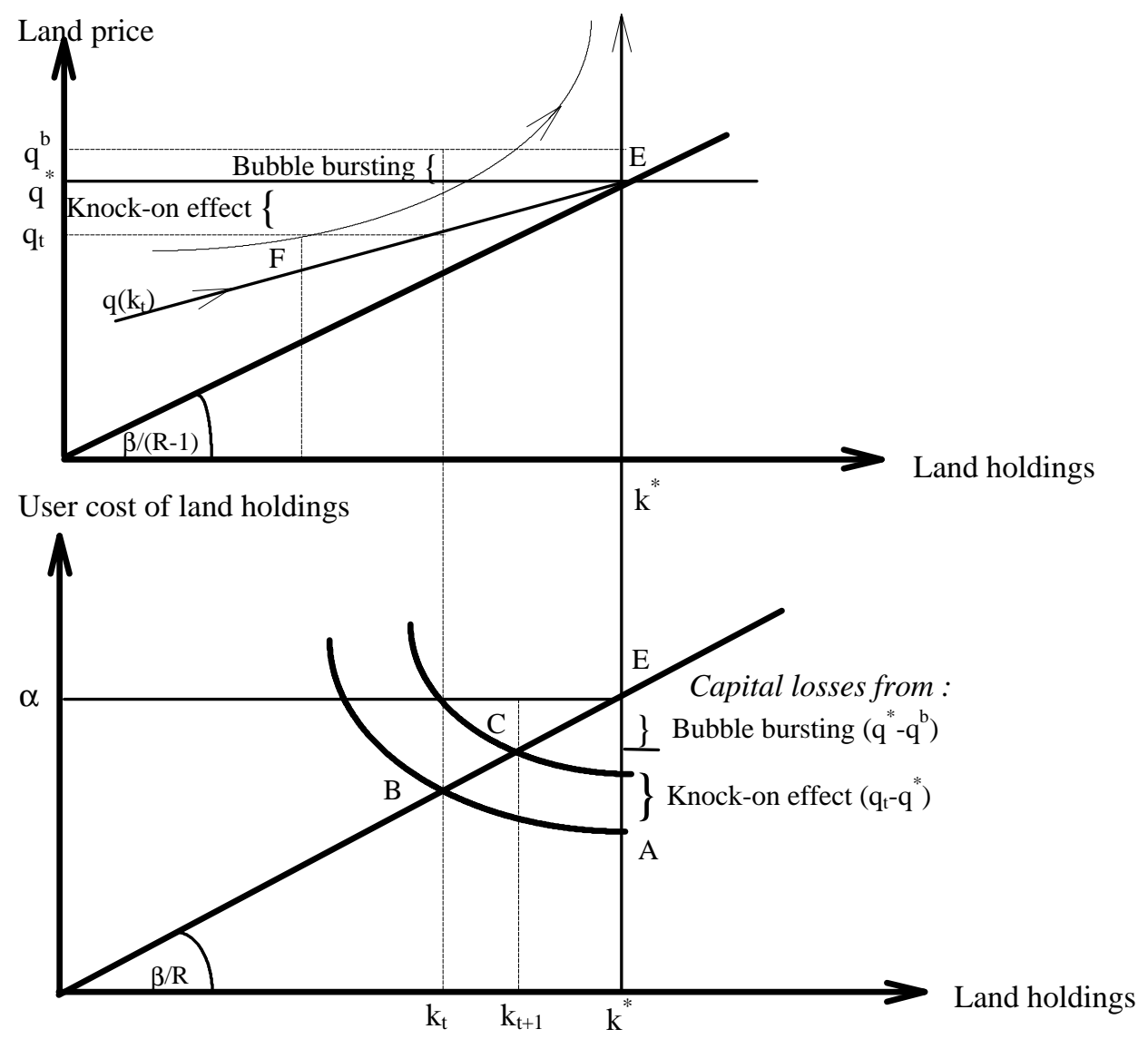

Fig. 3. Impact of the bubble bursting of land allocation and land price

How will this process play out? We can answer this for the period immediately after the unanticipated shock by using the formal solutions obtained by KM, replacing the productivity shock; $\Delta \alpha$, in (10) by $\mathrm{q}^{*}-\mathrm{q}^{\mathrm{b}}$, the excess of the bubble above equilibrium. This gives the 'first-period out-turn' as:

$$
\frac{\beta\left(\mathrm{k}_{\mathrm{t}}\right)^{2}}{\mathrm{R}}=\left(\alpha+\mathrm{q}_{\mathrm{t}}-\mathrm{q}^{*}-\left(\mathrm{q}^{\mathrm{b}}-\mathrm{q}^{*}\right)\right) \mathrm{k}^{*}=\left(\alpha+\mathrm{q}_{\mathrm{t}}-\mathrm{q}^{\mathrm{b}}\right) \mathrm{k}^{*}
$$

On the LHS is the total net-of-borrowing cost of holding land $\mathrm{k}_{\mathrm{t}}$ and the RHS measures the net worth of the firms at the end of period $t-1$, after bubble has burst. The land prices will of course initially fall below equilibrium because of the forced land sales; but, providing the property companies do not go out of business, it will recover and converge back to equilibrium at $\mathrm{q}^{*}$. As the property companies are so highly levered, there is a clear danger that a big enough fall in land values will reduce their net worth to zero and lead to bankruptcy.

If there is no general bankruptcy, the outcome is shown graphically in the top panel of Fig. 3 with first-period equilibrium at $\mathrm{k}_{\mathrm{t}}$ and land price of $\mathrm{q}_{\mathrm{t}}$. The fall of the land price from $\mathrm{q}^{\mathrm{b}}$ to $\mathrm{q}_{\mathrm{t}}$ is divided into the initial effect of the bubble bursting and the multiplier effect of land 
sales, what KM (1997, p.212) refer to as the 'knock-on effect'. In the lower panel, we illustrate (for m equal zero) how these unanticipated capital losses shift the firms' net worth constraint down from $\mathrm{E}$ to the rectangular hyperbola labelled $\mathrm{AB}$. Point $\mathrm{B}$, where net worth constraint matches the user cost of land, is the first-period equilibrium. (If there are no more surprises, the subsequent evolution is as described previously, see point $\mathrm{C}$ in the figure).

But initial capital losses compounded by the 'knock-on' effect of land sales can easily reduce net worth of the highly levered firms to zero forcing wholesale liquidation of the creditconstrained sector as we show by calibrating the simple linear quadratic model described above. The extraordinary sensitivity of the model to asset price shocks remains even if lenders impose margin requirement for prudential and other reasons as we show by finding the largest shock (the 'maximum bubble') consistent with a return to equilibrium. The figures are purely illustrative and they doubtless exaggerate the fragility of equilibrium. (In their simulations, KM assume user costs and land prices which are much less sensitive to land sales than assumed here. How this could provide more realistic results by increasing robustness of equilibrium is shown in Appendix 4.)

Table 3.

Out-turns when land values are sensitive to land sales

\begin{tabular}{|l|r|r|r|r|}
\hline & $\mathrm{m}=0$ & \multicolumn{3}{|c|}{$\mathrm{m}=0.3$} \\
\hline & $\mathrm{k}_{\mathrm{t}-1}=\mathrm{k}^{*}$ & $\mathrm{k}_{\mathrm{t}-1}=\mathrm{k}^{*}$ & $\mathrm{k}_{\mathrm{t}-1}=0.5^{\#}$ & $\mathrm{k}_{\mathrm{t}-1}=0.5$ \\
\hline a) Land holdings and prices & & & & \\
Land holdings & & & & \\
- Before crash & 1 & 1 & 0.5 & 0.5 \\
- After crash ( $\mathrm{k}_{\mathrm{c}}$ ) & 0.99 & 0.52 & 0.25 & 0 \\
Land prices & & & & \\
\hline
\end{tabular}




\begin{tabular}{|c|c|c|c|c|}
\hline - Before crash $\left(q^{b}\right)$ & 100 & 103.25 & 93.90 & 99.30 \\
\hline - After crash $\left(q_{t}\right)$ & 99.98 & 85.16 & 76.60 & 68.80 \\
\hline (1) Bubble & 0.0001 & 3.25 & 11.25 & 17.70 \\
\hline (2) Knock-on effect & 0.02 & 14.84 & 7.80 & 15.60 \\
\hline (3) Total Crash & 0.02 & 18.09 & 19.05 & 33.30 \\
\hline b) Budget constraint & & & & \\
\hline Sources of funds & & & & \\
\hline - Income $\left(\mathrm{ak}_{\mathrm{t}-1}\right)$ & 1 & 0.7 & 0.4 & 0.4 \\
\hline - Borrowing $\left(b_{t}\right)$ & 98 & 31 & 46.2 & 34.8 \\
\hline Uses of funds & & & & \\
\hline - Land accum/dec $\left(\mathrm{k}_{\mathrm{t}}-\mathrm{k}_{\mathrm{t}-1}\right) \mathrm{q}_{\mathrm{t}}$ & -1 & -40.6 & -19.2 & -34.4 \\
\hline - Debt repaid $\left(\mathrm{Rb}_{\mathrm{t}-1}\right)$ & 100 & 72.3 & 65.7 & 69.5 \\
\hline
\end{tabular}

The parameters used to generate the results in Table 3 are $\mathrm{R}=1.01, \beta=1, \alpha=1 / 1.01$, which, with full leverage $(\mathrm{m}=0)$, give equilibrium values $\mathrm{q}^{*}=100$ and $\mathrm{k}^{*}=1$. In part $(\mathrm{a})$, columns 1 and 2, we show land prices and land holdings by property companies before and after a crash which involves the largest bubble consistent with their survival (and the solution technique is given in Appendix 3). For fully levered property companies, the first column demonstrates the extreme fragility of the $\mathrm{KM}$ model with 100 percent leverage as the 'maximum bubble' is effectively zero. In the second column, where leverage is 30 percent, the maximum bubble is 3.25 percent. The total fall in property prices will of course be a good deal of larger than that because of the impact of land sales needed to satisfy the margin requirement after bubble bursts, which lead to a 'knock-on' effect of about 15 percent in this case: and the maximum crash in land values (bubble plus knock-on) which can be sustained without wholesale liquidation is a little under a fifth.

Assuming they survive, it might be useful to see how the property firms react to a crash in property values. Consider the sources and uses of funds for partly levered firms given in part (b) column 2 (which, for convenience, are measured on a scale where the equilibrium value of their land holdings, $\mathrm{q}^{*} \mathrm{k}^{*}$, is 100 ). The debt to be repaid, 70 per cent of pre-crash land holdings plus interest, amounts to 72 . How is this achieved? The answer is primarily from land sales (41); secondly from new borrowing (31); and hardly at all from current income (a mere 0.7). Note how the credit constraints tighten as lenders, far from rolling over the loans, cut their financing by more than half so to ensure that it is no more than $70 \%$ of expected future 
land holdings at post-crash prices. Caught in a spiral of tightening credit constraints and falling land values, the companies have to dispose of almost half their land holdings at knock-down prices (land which they will have to buy back later at higher prices, as they return to equilibrium).

Note that if a bubble bursts when land holdings are below equilibrium, see point $\mathrm{F}$ in Fig. 3, the likelihood of collapse is substantially reduced. (This because to the left of equilibrium, productivity lies above user cost and this provides a cushion against negative shocks not available at equilibrium.) The last two columns of Table 3 provide two illustrations where the initial land holdings of property companies are only half of the equilibrium level. In the third column, a bubble which bursts 11 percent above the path to equilibrium leads to a disposal of half these holdings but there is no danger of financial collapse: it takes the bursting of a substantially larger bubble - 17.7 percent - to reduce the net worth of firms to zero, as they sell all their land and go out of business (see column 4).

The clear message emerging from these results is that highly levered firms who cannot raise outside finance are very vulnerable to asset price shocks ${ }^{10}$, at least when land holdings are at or close to equilibrium. If land prices are sensitive to asset sales - and firms buy land with a $30 \%$ margin - an initial asset price disequilibrium of as little as $3 \%$ could rise to $18 \%$ as margin requirements force property companies into selling land: and any bigger shock would drive them into liquidation.

\subsection{Foreign currency borrowing}

In an open economy where a fraction $\mathrm{f}$ of total borrowing to finance land purchases takes the form of unhedged foreign currency loans, there is another powerful source of disequilibriuman unanticipated shock to the exchange rate. Consider, for example, the effect of a one-period unexpected devaluation, $\delta$, which raises local currency value of total borrowing by $(1-\mathrm{m}) \mathrm{f} \delta$. To see how this could drive the system away from equilibrium, compare the effects with that of a bubble bursting. Note that the required debt repayment in period $t$ is now $(1-\mathrm{m})(1+\mathrm{f} \delta) \mathrm{q}^{*} \mathrm{k}^{*} / \mathrm{R}$, whereas when a bubble burst at $\mathrm{q}^{\mathrm{b}}>\mathrm{q}^{*}$, required debt repayment in period $\mathrm{t}$ was $\mathrm{q}^{\mathrm{b}} \mathrm{k}^{*} / \mathrm{R}$. So, the two different shocks will give the same initial values for $\mathrm{q}$ and $\mathrm{k}$ if $\mathrm{q}_{\mathrm{b}}=(1-\mathrm{m})(1+\mathrm{f} \delta) \mathrm{q}^{*}$. Thus a 
$\delta$ percent rise in the price of foreign currency will have the same effect on the property market as a $(1-\mathrm{m}) \mathrm{f} \delta$ percent collapse in land prices.

By considering the KM model in an open economy setting, we find that, where unhedged short-term borrowing in foreign currency is a significant source of finance for land holdings, the financial sector is highly exposed to exchange rate movements. It is not only domestic asset bubble which can lead to the collapse of property sector: speculative attacks on currency can do so too.

\section{Financial stabilisation - Temporary financing}

The KM model shows how the response of credit-constrained borrowers to a temporary negative shock involves a persistent reduction of their net worth and a socially inefficient allocation of land. This is presumably something to be avoided in general. But if the negative shock is the end of a bubble this is less clear, for it could be a useful way of 'punishing' speculative excess. It could also be a harsh lesson on the risks of taking substantial open positions in foreign currency. But the model also implies that the punishment could prove too Draconian, leading to the collapse of the whole sector, which will surely pose systemic risks for the lenders. This is when temporary financing by lenders could play a useful role.

Using a simple two period example, we show in Fig. 4 how temporary finance could prevent an adverse shock from causing the collapse of the whole property sector. There the LHS of the first-period out-turn, (11), is plotted as the quadratic UU with equilibrium at point $\mathrm{E}\left(\right.$ where $\left.\mathrm{u}\left(\mathrm{k}^{*}\right) \mathrm{k}^{*}=\alpha \mathrm{k}^{*}\right)$. After replacing $\mathrm{q}_{\mathrm{t}}-\mathrm{q}^{*}$ by the linear approximation $\theta\left(\mathrm{k}_{\mathrm{t}}-\mathrm{k}^{*}\right)$, we plot the RHS of (11) - the net worth of all property companies - as the line NN, with slope $\theta \mathrm{k}^{*}$. With a sufficiently large shock, the net worth constraint, NN lies everywhere below UU so there is no way the credit-constrained firms can survive: so the property sector, unaided, will collapse.

Fearful of 'systemic risk', let the lenders provide financing $\mathrm{F}$ when the shock occurs, to be repaid as RF one period later. This extra money shifts the financing constraint up from NN to $\mathrm{MM}$ giving the first period at $\mathrm{k}_{\mathrm{F}}{ }^{0}$ and averting the collapse. Repayment of the finance provided lowers the net worth constraint by RF in the next period and this reduces the expansion in the next period as shown in Fig. 4. (Such prompt repayment may involve reducing land holdings to below their first period level.)

\footnotetext{
${ }^{10}$ Note, however, that the liquidity problems facing the credit-constrained firms in this model would be greatly
} 


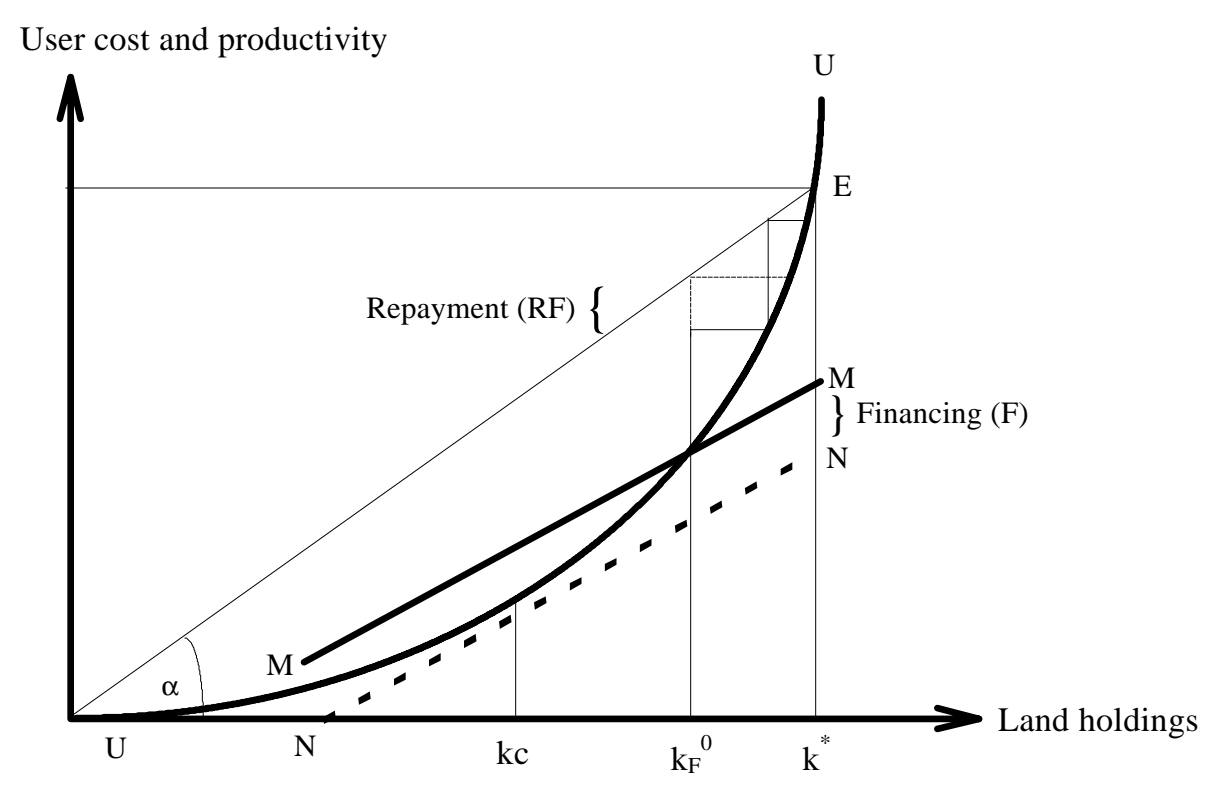

Fig. 4. How financing reduces the fall in land values and prevents collapse

The effect of rolling over loans is like having a 'lender of the last resort' in a financial system. So long as borrowers are still solvent after the initial shock, temporary financing can reduce (or avoid) the multiplier or 'knock-on' effects that come from the dumping of 'illiquid' assets in a scramble for liquidity and so prevent illiquidity becoming insolvency.

The unit elastic user costs assumed in calculating Table 3 imply that land is relatively illiquid, so the 'knock-on' effects are very large and there is a key role for emergency financing. But it would probably only go to the firms with partial leverage, as the fully levered firms are so exposed that they are likely to go bankrupt anyway, as we discuss in the next section.

\section{Domino effects}

Let there be two types of property companies, prudent operators who are partially levered and the imprudent who are fully levered. It is clear that in response to even a 'small' shock the imprudent firms will go bankrupt. What about the prudent companies? Thanks to their equity cushion, they should be able to survive the capital losses directly attributable to the initial shock. But they also have to cope with the fall in land prices stemming from the liquidation of imprudent firms; and this may prove impossible if the proportion of prudent companies is sufficiently small. So one might well observe a 'domino' effect where the collapse of the 
unlevered companies triggers a fall in asset values sufficient to overwhelm the defenses of the prudent firms and force them into liquidation. Unchecked, this could lead to bankruptcy of all property companies.

We first illustrate the nature of these financial 'avalanches' with the help of Fig. 5 and the calculations reported earlier. At point $\mathrm{E}$ in the figure, property companies in total hold $\mathrm{k}^{*}$ of land, with half held by imprudent companies, $\mathrm{k}_{\mathrm{l}}$, and half by prudent companies, $\mathrm{k}_{\mathrm{p}}$. Let the shock be an asset bubble bursting at $\mathrm{q}^{\mathrm{b}}$, which is above the sustainable level for imprudent firms but not for prudent firms. The former will go out of business: what about the latter? As shown in the figure, the value of land relative to future equilibrium at $\mathrm{k}^{*}$ (where prudent firms hold all the land) is given by the schedule EA whose slope $\theta$ depends on the speed of adjustment of the prudent firms. For $m=0.3$, we find $\theta=31.2$, see Table A.4 in Appendix 3, so the land values would fall by about 15.6 percent at point A relative to equilibrium at $\mathrm{q}^{*}$. Together with an initial bubble of say 3 percent this gives the total fall of over $18 \%$ from the bubble plus land sales by the imprudent companies.

At first sight it might appear that there is no risk of bankruptcy for the prudent firms as their net worth is about 31 and initial losses on land only 18 . But this leaves out of account the 'knock-on' effect of the land sales needed to satisfy the margin requirement (bearing in mind that the value of their collateral has fallen sharply relative to borrowing contracted at the land price of 103). Can their balance sheets withstand this multiplier effect? Referring to the last column of Table 3 we note that the largest 'exogenous' shock to land prices that prudent companies (with a 30\% margin of own funds) can stand when they are half way to equilibrium is only $17.7 \%$. So the prudent firms will be dragged down too: and reducing the ratio of prudent to imprudent firms in population, will of course increase the likelihood of this domino effect where capital losses overwhelm the prudent firms. 


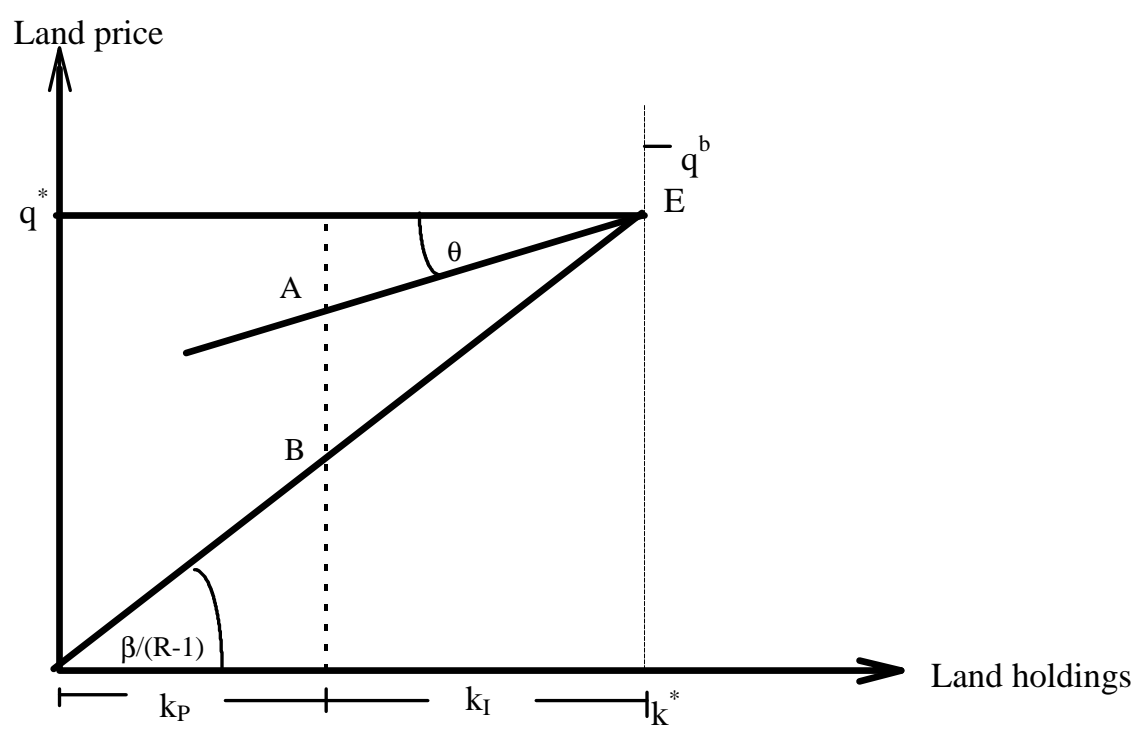

Fig. 5. The domino effect

This seems a good case for emergency financing: after all the prudent firms were solvent but for the 'knock-on' effect. In the context of credit-constrained firms, moreover, it appears that high leverage generates a large negative externality: so substantial margin requirements may need to be imposed for prudential reasons.

Domino effects may, of course, operate across sectors as well as within them, and may indeed operate across national frontiers. The failure of property companies after speculative bubble, for example, may put at risk the survival of other financial institutions such as banks and near-banks. And if other financial institutions are based in other countries, this will constitute a form of 'contagion'.

\section{Policy solutions: Handling corporate failure}

In their book on bank regulation, Dewatripont and Tirole (1994) list four ways for a regulatory agency to handle failure of banks which will be useful here. The first is liquidation, where the institution is closed and put under receivership. Second is a merger where a healthy institution acquires all (or some of) failing institution's assets and liabilities. Third is a provision of loans or transfers where, for example, the supervisory agency purchases or guarantee some of the bad loans to keep the institution afloat. Fourth is nationalisation where the government take full control of the failing institutions. 


\subsection{Liquidation}

In illustrating the domino effect, we had a dramatic example of the first strategy as all the imprudent companies were effectively put into receivership. It was also an indication of the risks of so doing, as the wholesale disposal of the assets of imprudent companies also brought down the prudent ones! The prudent companies though illiquid were essentially solvent, so one remedy would be to provide them with temporary financing which would avoid the second round of land sales which brought them down. Another is to adopt the second strategy, that of merger.

\subsection{Launching a lifeboat}

In this case, the idea is to get the prudent institutions to take over the imprudent as going concerns, which avoids wholesale liquidation and the collapse of asset prices. As Dewatripont and Tirole (1994, p.68) note, the regulator may need to make cash payments or buy some of the failing institutions (bad) assets at an inflated price to facilitate the purchase.

Alternatively, it could exercise forbearance (which consists in lowering the capital adequacy requirement or not enforcing it). In our domino example, a combination of a lifeboat and forbearance would seems sufficient for the purpose: if the prudent banks took over the imprudent banks and margin requirement were halved, the industry would be solvent and there would be no need for land sales.

In the Japanese banking industry, the merger strategy (or convoy as it is sometimes called there) has been so widely used as a constitute a form of mutual insurance. Fries, Mason, and Perraudin (1993, p.360) describe the situation and also indicate its limitations:

"In Japan, as far as possible, the authorities have dealt with troubled banks, without drawing on Deposit Insurance Corporation funds, by persuading other, healthy banks to carry out rescues. This policy has been pursued so systematically that one might describe the Japanese system in the past as representing mutual insurance by banks. Traditionally, a distressed bank would be bailed out by its 'group bank,' i.e., the main bank in one of the informal groupings of companies to which many Japanese firms belong."

"Such a system may be compared with the informal system of so-called 'lifeboats' organised in the past by the Bank of England whereby profitable banks would voluntarily participate in rescues. Recently UK banks have shown themselves unwilling to take part in such rescues and the Bank of England has had to rely on liquidations (as in case of BCCI) or on taking over the failing institution itself (as in case of Johnson Matthey). In deregulated 
markets, mutual insurance arrangements may still work well if placed on a more formal basis. [But]

...since in Japan there is no formal basis for the effective mutual insurance arrangements, the system depends crucially on the authorities' ability to coerce healthy banks into lending their assistance. As deregulation proceeds, the leverage available to the authorities will inevitably diminish."

\subsection{Transfers}

The third approach is the provision of loans or transfers to keep the failing institution from bankruptcy. Note that for banks this 'open-bank assistance', as it is called in the United States, "may be accompanied with concessions from management (which may also well be replaced) and uninsured creditors and shareholders who are asked to bear some of the losses", Dewatripont and Tirole (1994, p.68).

In the context of the model we have been examining, it is easy to see how transfers in the form of debt write-downs could avert bankruptcy. They would reduce outstanding borrowing and increase the net worth of credit-constrained firms in precisely in the opposite way to the unanticipated devaluation. (As KM point out (page 229), debt forgiveness alters (11) by introducing the term $\Delta \mathrm{bk}^{*}$ on the right hand side: so if the value of debt forgiven matches the losses from the bubble and/or devaluation, the system can go straight to equilibrium at E.)

While such 'transfers' could technically avert bankruptcy in our example, they would surely pose an enormous problem of 'moral hazard' if anticipated on a regular basis. Far from taxing financial obligations which involve systemic risk, debt write-offs for losses incurred on unhedged borrowing act as a subsidy: and bailing out property companies from the losses they make speculating on property is a recipe for speculative frenzy and repeated calls for more forgiveness. How long would it be before it was the lenders themselves who went bankrupt? It is presumably for this reason that the restructuring plans recommended for countries in East Asia by the international financial agencies (IMF and World Bank) eschew wholesale bailouts.

\subsection{Nationalisation}

A number of large troubled Latin-American banks were nationalised in the 1980s and in Scandinavia in the 1990s. This strategy is now being used in East Asia. In Thailand, for 
example, as part of the financial restructuring package recommended by the IMF, the Financial Institutions Development Fund (FIDF) is to become a major shareholder in four banks and turn them into state enterprises.

\subsection{A temporary freeze or 'circuit breaker'}

Another strategy for avoiding the collapse of land prices has been followed in East Asia. In Thailand, for example, the operations of property companies have simply been 'frozen' since the middle of 1997. (Presumably one reason for this was the suspension and subsequent closure of 56 of the 91 finance companies who provided funds for the property companies; another is that bankruptcy law is not well-developed and the cumbersome court procedure can take up to 5 years to foreclose.)

Like the circuit breaker operated in the US stock market, this freeze may avoid panic selling: but it is unlikely to prevent a substantial mark-down in land prices when the freeze ends. (In early 1998, it was reported that the Thai Land Department was preparing to revise downward the official reference prices of land by at least 45 percent for land plots in Bangkok, its vicinity and major provinces.)

\section{Conclusion}

A number of economists have blamed credit market imperfections for the depth and persistence of the Great Depression in the USA. Could similar mechanisms have played a role in ending the East Asian miracle?

We have used the KM model of highly levered credit-constrained firms to explore this question. First, we noted that the existence of speculative bubbles may not be so implausible as highly geared investors gamble on their upside potential (leaving their creditors to worry about the downside). Second, we confirmed that the response of credit-constrained firms to financial shocks - like the ending of the asset bubble or the fall of the exchange rate - can greatly amplify their effects. Falling asset values lead to loans being recalled: and selling assets to gain liquidity can exacerbate rather than relieve the shortage of liquidity. For this reason, the initial equilibrium is very sensitive to shocks. In the absence of appropriate stabilisation policy, it was shown how the sudden ending of asset bubble (or an exchange rate peg) could even lead to financial collapse, where - like falling dominoes - prudent firms are brought down by imprudent firms. One could characterise the KM model as one of multiple equilibria, where the bad equilibrium is unstable and the good equilibrium is very fragile! 
As applied to land-holding property companies, a model of highly-levered creditconstrained firms illuminates role of credit market can play in financial crisis like that in East Asia. Excess credit creation can easily raise asset values above equilibrium; but when this disequilibrium is being corrected, credit constraints can set in motion a vicious downward spiral in asset prices.

Key to avoiding financial collapse is the nature of financial stabilisation policy; temporary financing can prevent illiquidity becoming insolvency; and launching 'lifeboats' can do the same. These may be effective crisis measures; but the vulnerability of the financial systems in East Asia to shocks coming from short-term foreign borrowing suggests the need for prevention. Chile and Columbia have shown how banks can be discouraged from largescale short-term borrowing in foreign currency: they effectively tax short-term borrowing more than long term. The justification for such 'taxes' on capital movements is that they can reduce a negative externality, namely the sort of systemic collapse analysed in this paper.

\section{Appendix 1: Macroeconomic conditions in the KIT economies}

Table A.1. South Korea economic indicators

\begin{tabular}{|l|r|r|r|r|}
\hline & Avg. 1991 - 1995 & 1996 & 1997 & $1998^{\mathrm{f}}$ \\
\hline Real GDP \% change & 7.5 & 7.1 & $6.1^{\mathrm{e}}$ & $-2.0^{\mathrm{f}}$ \\
Consumer Price Inflation \% & 5.9 & 4.9 & $6.6^{\mathrm{e}}$ & $11.8^{\mathrm{f}}$ \\
Current Account Bal \$bln & -4.3 & -23.5 & $-12.1^{\mathrm{e}}$ & $17.1^{\mathrm{f}}$ \\
$\quad$ \% of GDP & -1.2 & -4.9 & $-2.7^{\mathrm{e}}$ & $6.9^{\mathrm{f}}$ \\
International Reserves \$bln & 21.9 & 33.2 & 16.7 & $30^{\mathrm{f}}$ \\
Total external debt \$bln & 66.5 & 142.1 & 155.3 & $155.1^{\mathrm{f}}$ \\
short term \$bln & 28.7 & 75.6 & 60.1 & $42.1^{\mathrm{f}}$ \\
\hline
\end{tabular}


Table A.2. Indonesia economic indicators

\begin{tabular}{|l|r|r|r|r|}
\hline & Avg. 1991 - 1995 & 1996 & 1997 & $1998^{\mathrm{f}}$ \\
\hline Real GDP \% change & 7.1 & 7.8 & $7.0^{\mathrm{e}}$ & $-1.5^{\mathrm{f}}$ \\
Consumer Price Inflation \% & 8.7 & 6.6 & $11.0^{\mathrm{e}}$ & $10.0^{\mathrm{f}}$ \\
Current Account Bal \$bln & -3.9 & -7.8 & $-8.8^{\mathrm{e}}$ & $1.6^{\mathrm{f}}$ \\
$\quad$ \% of GDP & -2.5 & -3.4 & $-4.5^{\mathrm{e}}$ & $1.3^{\mathrm{f}}$ \\
International Reserves \$bln & 15.8 & 24.1 & 28.1 & $32.1^{\mathrm{f}}$ \\
total external debt \$bln & 96.4 & 121.4 & 131.4 & $134.4^{\mathrm{f}}$ \\
short term \$bln & 19.4 & 28.6 & 26.6 & $21.6^{\mathrm{f}}$ \\
\hline
\end{tabular}

Table A.3. Thailand economic indicators

\begin{tabular}{|l|r|r|r|r|}
\hline & Avg. 1991 - 1995 & 1996 & 1997 & $1998^{\mathrm{f}}$ \\
\hline Real GDP \% change & 9 & 6.7 & $0.5^{\mathrm{e}}$ & $-2.5^{\mathrm{f}}$ \\
Consumer Price Inflation \% & 4.9 & 4.8 & $8.5^{\mathrm{e}}$ & $12.1^{\mathrm{f}}$ \\
Current Account Bal \$bln & -8.4 & -14.7 & $6.6^{\mathrm{e}}$ & $5.3^{\mathrm{f}}$ \\
$\quad$ \% of GDP & -6.5 & -7.9 & $4.2^{\mathrm{e}}$ & $4.8^{\mathrm{f}}$ \\
International Reserves \$bln & 25.5 & 37.7 & 28.7 & $30.7^{\mathrm{f}}$ \\
total external debt \$bln & 57.9 & 98.4 & $102.4^{\mathrm{e}}$ & $108.4^{\mathrm{f}}$ \\
short term \$bln & 26.5 & 37.9 & $31.9^{\mathrm{e}}$ & $26.9^{\mathrm{f}}$ \\
\hline
\end{tabular}

Source: IMF Statistics various issues and JP Morgan World Financial Markets 1998Q1 Report Note that 'e' accounts for 'estimate' and 'f' represents 'forecast'

\section{Appendix 2 : Margin requirement}

With the margin requirement, the borrowing constraint can be rewritten as

$$
b_{t}=\frac{(1-m) q_{t}+1 k_{t}}{R}
$$

where $\mathrm{m}$ denotes margin requirement or loan-to-value ratio.

Substituting (A.1) into the budget constraint, (1), and re-arranging yields

$$
\mathrm{u}_{\mathrm{t}} \mathrm{k}_{\mathrm{t}}=\mathrm{ak}_{\mathrm{t}-1}+\mathrm{mq}_{\mathrm{t}} \mathrm{k}_{\mathrm{t}-1}-\frac{\mathrm{mq}_{\mathrm{t}+1 \mathrm{k}_{\mathrm{t}}}}{\mathrm{R}}
$$


or

$$
\left[\mathrm{q}_{\mathrm{t}}-\frac{(1-\mathrm{m}) \mathrm{q}_{\mathrm{t}+1}}{\mathrm{R}}\right] \mathrm{k}_{\mathrm{t}}=\left(\mathrm{a}+\mathrm{mq}_{\mathrm{t}}\right) \mathrm{k}_{\mathrm{t}-1}
$$

Solving the linearlised difference equations for land holdings and land price obtain the slope of stable path as follows

$$
\theta^{\prime}=\frac{\mathrm{b}}{\mathrm{R}-\left[\frac{1+\frac{\mathrm{Rm}}{(\mathrm{R}-1)(1-\mathrm{m})}}{2+\frac{\mathrm{Rm}}{(\mathrm{R}-1)(1-\mathrm{m})}}\right]}
$$

\section{Appendix 3. Solution technique and Parameter values}

\section{Solution technique}

To illustrate the solution techniques we use to answer question see Fig. A1 where we plot the LHS of (6) as the quadratic UU and the equilibrium at point E (where the UU crosses the line $\alpha \mathrm{k}$, not shown). After replacing $\mathrm{q}_{\mathrm{t}}-\mathrm{q}^{*}$ by the linear approximation $\theta\left(\mathrm{k}_{\mathrm{t}}-\mathrm{k}^{*}\right)$, we plot the RHS of (6) - the net worth of all property companies - as the line $\mathrm{NN}$, with slope $\theta \mathrm{k}^{*}$, which is tangent to $\mathrm{UU}$ at point $\mathrm{C}$. At this point, the net worth of all property firms is just sufficient to provide the down payment of land holdings, $\mathrm{k}_{\mathrm{c}}$, so the distance $\mathrm{EF}$, which measures $\left(\mathrm{q}^{\mathrm{b}}-\mathrm{q}^{*}\right) \mathrm{k}^{*}$, indicates the size of the largest bubble consistent with survival of the property companies. Any larger the bubble would lower NN, ruling out any intersection: so there is no way the creditconstrained firms could survive. A smaller bubble would, however, shift the net worth schedule upwards, giving the intersection to the right of $\mathrm{k}_{\mathrm{c}}$ (and another equilibrium to the left, which we ignore). 


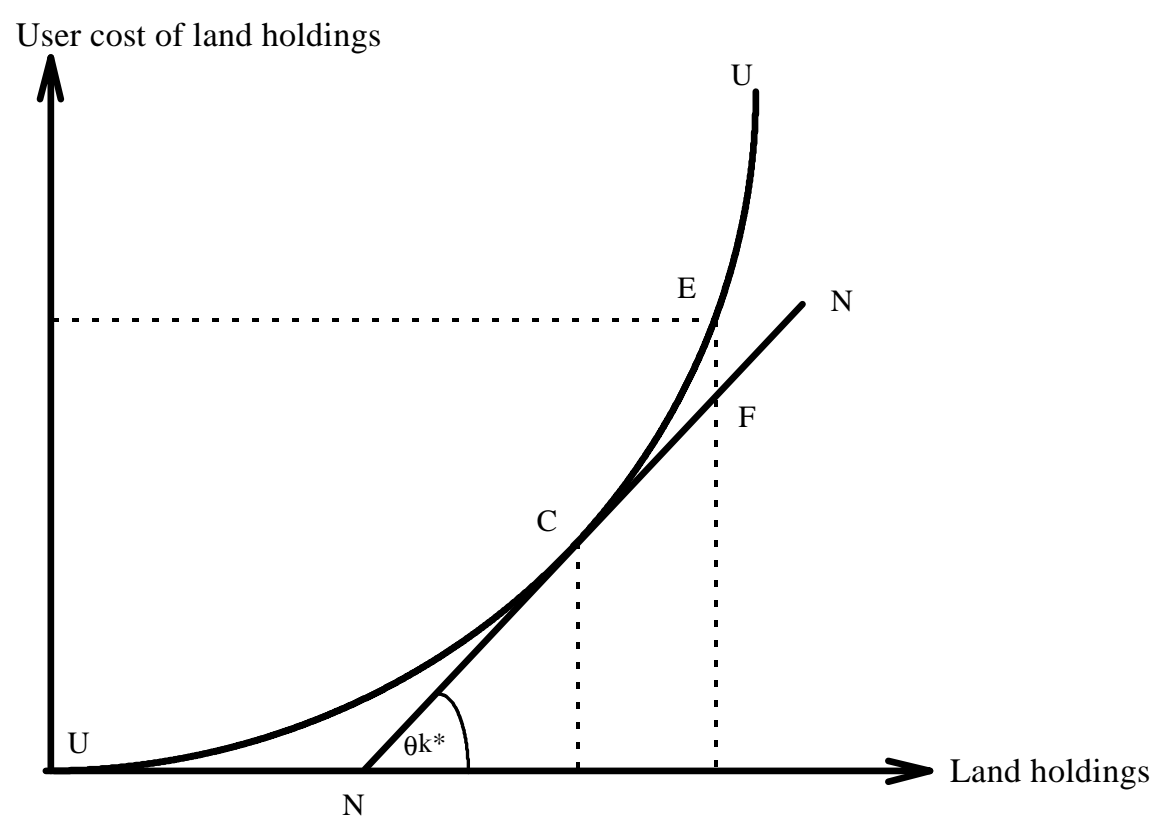

Fig. A1. Net worth and user cost

Once $\mathrm{q}_{\mathrm{t}}-\mathrm{q}^{*}$ is replaced by $\theta\left(\mathrm{k}_{\mathrm{t}}-\mathrm{k}^{*}\right)$, equating the LHS and RHS of (6) defines a quadratic equation in $\mathrm{k}$, given the parameter $\theta$ which is obtained as a slope of the stable path of the dynamic system linearised around equilibrium. The size of the largest bubble is the value of $\mathrm{q}^{\mathrm{b}}$ which sets the discriminant equal to zero, and $\mathrm{k}_{\mathrm{c}}$ is associated value for $\mathrm{k}$.

\section{Parameter values}

We tabulate the parameter $\theta$, which measures the sensitivity of land prices to land sales, and $\phi$, the autoregressive coefficient in the process of capital accumulation, as the margin requirement increases from 0 up to 50 percent. It is interesting to see that the value of $\theta$ lies just above the percentage margin requirement. (So, if $\mathrm{m}$ equals 30 percent, for example, land prices fall below equilibrium by 31.2 times the percentage disposal of land by property companies.) If $\theta$ rises, this means that land prices are more sensitive to land sales. The reason that the higher $\mathrm{m}$ increases $\theta$ is that the margin requirements make it more difficult for company to expand (as they rely more internal funds and less on bank finance); this slows the speed of adjustment and moves land prices closer to user costs. (How dramatically adjustment slowdowns is indicated by sharp increase in $\phi$, the coefficient on lagged land holdings, from 0.5 in column one to 0.98 in column two, for example.)

Table A.4. Margin requirements, land price coefficients, and autoregressive coefficients 


\begin{tabular}{|l|l|l|l|l|}
\hline & \multicolumn{4}{|c|}{ Margin requirement (\%) } \\
\hline & 0 & 30 & 40 & 50 \\
\hline Elasticity =1 & & & & \\
$\theta$ & 1.96 & 31.2 & 40.9 & 50.7 \\
$\phi$ & 0.5 & 0.98 & 0.99 & 0.99 \\
\hline
\end{tabular}

\section{Appendix 4. Less elastic user cost of land}

The results reported in Table 3 are based on the assumption that the user cost per unit of land held by property companies rises in proportion to their land holdings - i.e., user costs are unit elastic: and this high elasticity helps to explain why the downward price spiral is so vicious, with prices falling many times more through land sales than from the bubble itself! In their simulations KM assumed the user cost is much less sensitive to changes in land-use : but the elasticity they use (only 1/10) would mean that prices hardly change. And there would be almost no such spiral. We tried reducing the elasticity of user costs, but not by so much, and found that a figure of $2 / 3$ limits the size of the knock-on effect, increases the maximum bubble and makes an equilibrium a good deal more robust, see Table A.5.

Table A.5. Out-turns with less elastic user costs of land (elasticity = 2/3)

\begin{tabular}{|l|r|r|r|}
\hline & \multicolumn{3}{|c|}{ Margin requirement (\%) } \\
\hline & 30 & 40 & 50 \\
\hline Bubble (\%) & 6 & 13 & 23 \\
Price after crash & 81 & 75 & 70 \\
Crash (\%) & 25 & 38 & 53 \\
Land holding after crash & 0.27 & 0.26 & 0.25 \\
\hline
\end{tabular}

With less elastic user costs but the same margin requirement of $30 \%$, the knock-on effect of land sales is reduced to three times the initial disequilibrium, as can be seen from the first column; so the maximum sustainable bubble is $6 \%$ and land disposals are limited to a quarter of initial holdings. Raising firm leverage to $40 \%$ allows them to sustain a bubble twice as large: and raising it to $50 \%$ almost doubles it again. So the last column illustrates how companies whose borrowings are limited to half their land holdings can sustain a crash measuring $53 \%$ of equilibrium land values by selling a quarter of their land. 


\section{References}

Allen, Franklin and Douglas Gale (1997), "Bubble and Crises," mimeo, presented at CEPR/ESRC/GEI Conference on The Origins and Management of Financial Crises, Cambridge, July.

Bernanke, Ben (1983), "Nonmonetary Effects of the Financial Crisis in the Propagation of the Great Depression," American Economic Review, vol.73, June, pp.257-276.

Bernanke, Ben and Mark Gertler (1995), "Inside of Black Box- the credit channel of monetary policy transmission," Journal of Economic Perspectives, 9 (4), pp. 27-48.

Blanchard, Olivier and Stanley Fischer (1989), Lectures on Macroeconomics, Cambridge, Massachusetts: MIT Press.

Bond, Timothy J and Marcus Miller (1998), "Financial Bailouts and Financial Crises," mimeo, IMF.

Dewatripont, Mathias and Jean Tirole (1994), The Prudential Regulation of Banks, Cambridge, Massachusetts: MIT Press.

Edison, Hali and Marcus Miller (1997), “The Hong Kong Handover: Hidden pitfalls,” mimeo, presented at CEPR/ESRC/GEI Conference on The Origins and Management of Financial Crises, Cambridge, July.

Fischer, Stanley (1998), “The Asian Crisis: A view from the IMF," as reported in IMF Survey, Washington, vol.27, no.2, January.

Fries, Steven, Robin Mason and William Perraudin (1993), "Evaluating Deposit Insurance for Japanese Banks," Journal of the Japanese and International Economies, vol.7, pp.356-386 
Gavin, Michael and Ricardo Hausmann (1996) "The Roots of Banking Crises: The macroeconomic context," in Hausmann and Rojas-Suarez (eds), Banking crises in Latin America, pp. 27-63.

Goldstein, Morris and Philip Turner (1996), "Banking Crises in Emerging Economies: Origins and policy options," BIS Economic Papers, No. 46, Basle: BIS.

IMF (1997) International Capital Market: Developments, Prospects and Key Policy Issues, International Monetary Fund, November.

Kaminsky, Graciela and Carmen Reinhart (1996) "The Twin Crises: The Causes of Banking and Balance of Payments Problems," mimeo, Board of Governors of the Federal Reserve, August.

King, Mervyn (1994), "Debt Deflation: Theory and evidence," European Economic Review, 38, pp.419-445.

Kiyotaki, Nobuhiro and John Moore (1997), "Credit Cycles,” Journal of Political Economy, vol 105, April, pp.211-248.

Krugman, Paul (1998), "What happened to Asia," mimeo.

Lindgren, Carl-Johan, Gillian Garcia, and Mathew I. Saal (1996), "Bank soundness and macroeconomic policy,” Washington D.C., International Monetary Fund.

Luangaram, Pongsak (1997), "Credit constraints, Collateral, and Crisis : Thailand experiences and theoretical modelling," MSc. Dissertation, September, University of Warwick.

Masson, Paul (1997), "Monsoon Effects, Spillovers, and Contagion,” Washington D.C., International Monetary Fund.

World Bank Report (1997) Private Capital Flows to Developing Countries: The Road to Financial Integration, Oxford University Press. 
